\title{
EFFECT OF MULTIDISCIPLINARY BOARD ON THE DIAGNOSIS AND TREATMENT OF ENDOCRINE DISEASES
}

\author{
MULTIDISIPLINER KURULUN ENDOKRIN HASTALIKLARIN TANI VE \\ TEDAVISINE ETKISI
}

\author{
Hamid Ahmet KABULI* (D), Ahmet Cem DURAL* (i), Cevher AKARSU* (1), \\ Mustafa Gökhan ÜNSAL** (D), İlkay HALICIOĞLU* ${ }^{*}$, Pinar KARAKAYA*** ㅁ, \\ Ravza YILMAZ**** (D), Deniz GÜZEY* (D), Halil ALIŞ* (D)
}

\begin{abstract}
Objective: We aimed to evaluate the outcomes of our multidisciplinary endocrine board (MEB) which is established for more specific treatment management of the patients with endocrine gland diseases.

Material and Methods: The MEB is established at 2012 in our institution. Prior to this date, the setup of board was a general tumor board (GTB) in which mostly malignant cases were discussed. The records of GTB rounds from January 2009 to September 2012, the records of MEB rounds from September 2012 to December 2014 and the endocrine surgery cases performed at our department since 2009 were retrospectively analyzed and compared.

Results: A total of 1012 patients were included the study. In GTB period, 336 patients, in MEB period, 599 patients underwent surgery for endocrine diseases. Only 94 of these patients who underwent surgery were discussed at GTB, dispite that, 582 cases were discussed at MEB $(\mathrm{p}<0.001)$. Benign, suspicious or malignant thyroid gland diseases $(\mathrm{n}=396)$ were most commonly discussed (68\%) at MEB. The total number of surgery for endocrine cases, thyroid, parathyroid and adrenal gland diseases were increased after the establishment of the $\operatorname{MEB}(\mathrm{p}=0.06, \mathrm{p}=0.13, \mathrm{p}=0.04$ and $\mathrm{p}=0.09$, respectively) when compared with GTB. Also the number of surgery for thyroid cancer and the requirement of prophylactic and therapeutic neck dissection were increased $(\mathrm{p}=0.10$ and $\mathrm{p}=0.03$, respectively).

Conclusion: In a field as complex as endocrine diseases, a special board should increase the quantity of more sophisticated cases, as well as the quality and effectiveness of disease management rather than a GTB.

Keywords: Endocrine system diseases; Interdisciplinary communication; Specialty boards

\section{ÖZET}

Amaç: Endokrin bez hastalığı olan hastalara daha spesifik tedavi yönetimi sağlanabilmesi amacı ile kurulmuş olan multidisipliner endokrin kurulumuza (MEK) ait sonuçlarımızı paylaşmayı amaçladık.

Gereç ve Yöntem: Kurumumuzda MEK 2012 yılında kurulmuştur. Bu tarihten önce, konseyin şekli genel tümör kurulu (GTK) olup, daha çok habis olgular tartışılmakta idi. Ocak 2009 -Eylül 2012 yıllarına ait GTK, Ekim 2012 - Aralık 2014

Cite this article as: Kabuli H.A., Dural A.C., Akarsu C., Ünsal M.G., Halıcı̆̆lu İ., Karakaya P., Yılmaz R., Güzey D., Alış H. Effect of multidisciplinary board on the diagnosis and treatment of endocrine diseases. J Ist Faculty Med 2018; 81(1): 25-31.

Dergiye geldiği tarih/Date received: 11.04.2017 - Dergiye kabul edildiği tarih/Date accepted: 06.02.2018

* University of Health Sciences, Faculty of Medicine, Bakırköy Dr. Sadi Konuk Training and Research Hospital, Department of General Surgery and ***Department of Endocrinology, Istanbul

**Adnan Menderes University, Faculty of Medicine, Department of General Surgery, Aydın

**** Istanbul University, Istanbul Faculty of Medicine, Department of Radiology, Istanbul

(İletişim kurulacak yazar/Corresponding author: cemdural@hotmail.com)
\end{abstract}




\section{Multidisciplinary board for endocrine diseases}

yıllarına ait MEK kayıtları ve kliniğimizde 2009 yılından beri ameliyat edilen endokrin cerrahi olgularına ait tıbbi kayıtlar retrospektif olarak değerlendirildi ve karşılaştırıldı.

Bulgular: Toplam 1012 hasta çalışmaya dahil edildi. GTK döneminde 336 hasta, MEK döneminde 599 hasta endokrin hastalıklar nedeniyle ameliyat edildi. Ameliyat edilen hastalardan 94'ü GTK'unda tartışılırken, 582'si MEK'unda tartışıldı $(\mathrm{p}<0,001)$. MEK'de çoğunlukla selim, şüpheli veya malign tiroid bezi hastalıkları $(n=396)$ tartışıldı (\%68). Tüm endokrin olgular, tiroid, paratroid ve adrenal gland hastalıkları için ameliyat sayıları MEK'unun kurulmasından sonra arttı ( $\mathrm{p}=0,06$; $\mathrm{p}=0.13 ; \mathrm{p}=0,04$ ve $\mathrm{p}=0,09$, sırasıyla). Aynı zamanda, tiroid kanseri ameliyatı sayısı ve profilaktik veya terapötik boyun diseksiyonu gereksinimi de artt $(\mathrm{p}=0,10$ ve $\mathrm{p}=0,03$, sirasiyla).

Sonuç: Endokrin hastalıklar gibi kompleks bir alanda, GTK'una kıyasla özel bir kurul daha sofistike olguların sayısını, aynı zamanda hastalık yönetiminin kalite ve verimini arttırabilir.

Anahtar Kelimeler: Endokrin sistem hastalıkları; disiplinler arası iletişim; özel kurullar

\section{INTRODUCTION}

Multidisciplinary disease management to the highest possible standards has become increasingly important when oncological surgical approaches are planned $(1,2)$. Inter-departmental networks are greatly strengthened by the now commonplace mortality and morbidity meetings, consultations, and meetings co-organized by various clinics $(2,3)$. Indeed, the standards of tumor boards required by the American National Institute of Health Standards were redefined in 2012 (4). At that time, the American Surgical Association made it mandatory for the tumor board to prospectively discuss all cases and decide on treatment options. This is a part of the accreditation program of the Cancer Commission (4).

Implementation of appropriate cancer treatment, dictated by the highest standards, is at least as important as early diagnosis (2). In our country, as is also true worldwide, major efforts are being made to define and improve the necessary standards (5). For the management of diseases of the endocrine system, particularly thyroid cancer, it is essential to define the most appropriate treatment plan and to implement logical disease management. It is necessary to develop appropriate guidelines, to evaluate the various treatment options and adjuvant therapies, and to schedule optimal follow-up (6). Endocrine system diseases are generally sophisticated, and interdisciplinary communication is integral to any discussion of histopathological findings (6).

Appropriate management, with avoidance of unnecessary diagnostic procedures and efficient use of time, can be achieved using a multidisciplinary approach. Moreover, such an approach enhances the perspective of all participants and improves the knowledge of novice doctors and other professional caregivers (5).
The literature contains a great deal of information on the positive effects of multidisciplinary boards (MB) in terms of follow-up strategies and the survival of cancer patients (6-8). However, a few data are available on the impacts of MBs on the care of patients with non-cancerous diseases, in the context of either long-term follow-up or treatment. In addition, little has appeared on the diagnosis, follow-up, or treatment of this complex group of disorders.

Here, we evaluated the role played by a specific MB established at our clinic to discuss both malignant and non-malignant endocrine disease requiring surgery, in terms of diagnosis, follow-up, and treatment.

\section{MATERIALS AND METHODS}

In our institution, all surgical cases for malignant diseases were discussed by a single MB prior to 2012. The design of this board was a general tumor board (GTB) and the primary purpose was to discuss the oncological cases. Hence, all thyroid patients with suspicious for malignancy were also evaluated at GTB. However, no any benign thyroid diseases for surgical indication or any parathyroid gland diseases were discussed in these meetings. Adrenal masses were discussed on GTB when detected in our surgical or urological outpatient clinics and imaging studies. Furthermore, GTB was consisted of surgeons, radiologist, pathologists, medical and radiation oncologists and there were no endocrinologists or specialists of nuclear medicine. In September 2012, instead of GTB, 4 different MBs were established such as Breast, Endocrine, Gastrointestinal and Hepatobiliary Surgery and separate weekly rounds were planned (9). Thus, the multidisciplinary endocrine board (MEB) consisted of endocrine surgeons, endocrinologists, pa- 


\section{Endokrin hastalıklar için multidisipliner kurullar}

thologists, radiologists and specialists of nuclear medicine (9). All organizational aspects, details of the format and patient evaluation algorithm of the MEB was described in our previous study (9).

According to this, after 2012, all thyroid gland patients with hyperthyroidism (Basedow Graves, toxic multinodulary disease, solitary toxic nodule), all suspicious thyroid nodules ( $\geq$ Bethesda 3 cytology findings), benign thyroid gland diseases with possible surgical indications (large goiters, retrosternal goiters) are discussed. The patients with benign findings but obvious indications for surgery according to our department's criterias were not presented at MEB (9). Moreover, all parathyroid gland (primary or secondary hyperparathyroidism) and adrenal gland pathologies were also reviewed. Patients histopathologically reported as malignant were also reviewed at the weekly MEB meetings (9). Patient information to be reviewed was registered in a board form within our hospital information management system by the providing physician, and prior to each meeting, was e-mailed to all MEB members by the officer of the board before the meeting. All decisions made in MEB meetings were recorded to online database by the board officer. After each meeting, the relevant physicians advised patients about MEB decisions, completed all necessary pre-operatory work-up, and provide patient guidance. Informed consent form was obtained from all patients before surgical or interventional procedures.

For this study, medical records of all patients who underwent surgery for endocrine diseases, the weekly GTB records from 2009 to September 2012, the weekly MEB records from September 2012 to December 2014 were analyzed in terms of the contributions made by specialists in general surgery, endocrinology, nuclear medicine, pathology, and radiology, the outpatient and inpatient medical and surgical records studied, reference to the average numbers of patients discussed weekly and monthly, the department that presented patients for discussion, MEB treatment recommendations, the work-up requested by MEB, the number of MEB rounds for the re-evaluation of the same patient, the specific conditions evident at admission and any increase in the number of such conditions after MEB evaluation; by interventions; and by the time elapsed from discussion by the MEB to treatment. All data were evaluated retrospectively and compared to data available from the GTB period if available. Thus, we compared the numbers of admissions to our department and interventions of patients with parathyroid and adrenal gland diseases, and all aspects of thyroid gland diseases before and after the establishment of the MEB.

Data were entered into a computerized database (Microsoft Excel 2007, Microsoft Inc., Redmond, WA) and encrypted for individual privacy protection. Approval by the local Ethics Committee was obtained on August 31, 2015 (File Number: 2015-137) and the study has been performed in accordance with the ethical standards laid down in the 1964 Declaration of Helsinki.

\section{Statistical Analysis}

Data were evaluated using JMP ${ }^{\circledR}$ software version 10.0.0 (SAS ${ }^{\circledR}$, Cary, NC). Means \pm standard deviations or medians (ranges) are presented. The chi-squared test was used to compare categorical variables. Student's t-test was used to compare continuous variables.

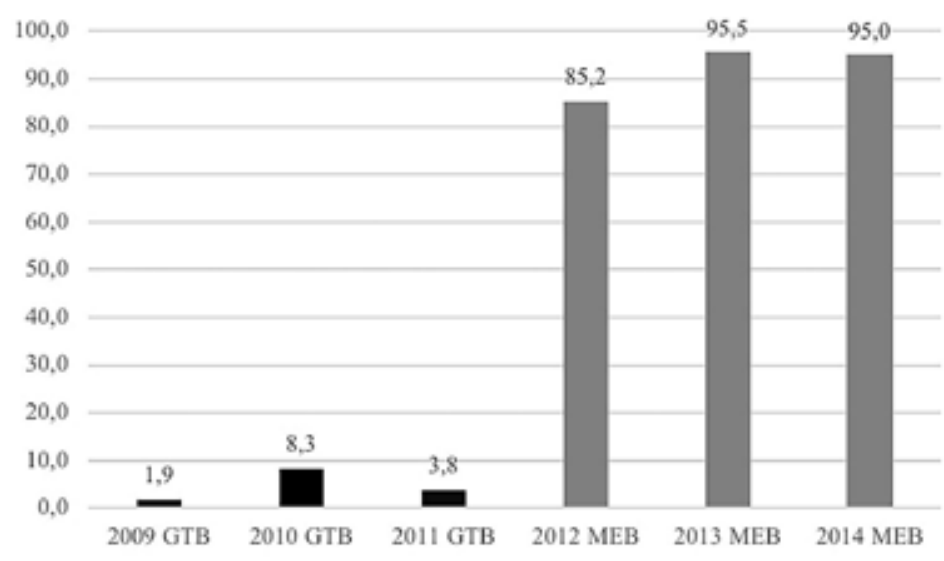

Figure 1. Endocrine cases discussed at GTB and MEB per year. 


\section{Multidisciplinary board for endocrine diseases}

A $p$ value $<0.05$ was considered to reflect statistical significance.

\section{RESULTS}

A total of 1012 patients were included to study. Of these, 935 underwent surgery for endocrine diseases. In the GTB period 336 patients, in the MEB period 599 patients underwent surgery. Due to the design of two different board meetings; 118 of these patients were discussed at GTB and medical treatment or follow-up was considered to 24 of these, 582 patients were discussed at MEB and medical treatment of follow-up was considered to 53 of these patients. The number of patients discussed for endocrine diseases was higher and the rate of their presentation in a MB was higher in the MEB rounds $(\mathrm{p}<0.001)$ (Figure 1). A total of 288 patients (49.5\%) were presented to the MEB by department of General Surgery, 213 (36.5\%) by Endocrinology, 51 $(8.8 \%)$ by Pathology, and 30 (5.2\%) by Nuclear Medicine (Figure 2). The median weekly and monthly numbers of cases discussed were 6 (2-14) and 23 (12-47), respectively.

In the MEB meetings, the majority of presented cases was thyroid gland diseases $(n=396 ; 68 \%)$ (Figure 3). Patients with suspicious or confirmed malignant cytology findings were $45.2 \%(\mathrm{n}=179)$ of the thyroid cases followed by benign thyroid pathologies $41.9 \%(n=166)$ discussed in terms of their surgical indications. Thirty two patients $(8.1 \%)$ directly presented by the department of Pathology and were discussed in terms of their histopathological findings. For the remaining 19 patients $(4.8 \%)$, follow-up or further evaluation was considered. A hundred nineteen patients $(20.4 \%)$ were presented as parathyroid gland diseases, a follow-up was considered in 4 patients. Remaining 115 patients underwent surgery after completing blood and imaging studies. Most of the parathyroid cases $(n=113 ; 94.9 \%$ of total parathyroid gland diseases discussed at MEB) were presented by the department of Endocrinology after completing their work-up. Thus, a surgical intervention was mostly considered to these patients at MEB. A total of 67 patients $(11.5 \%)$ had adrenal gland diseases, 37 of them underwent surgery after their pre-operative work-up and follow-up was considered for the remaining 30 of the patients.

Of all patients, $84 \%(n=489)$ were presented to the MEB only once, $13.9 \%(\mathrm{n}=81)$ twice, and $2.1 \%(\mathrm{n}=12)$ more than twice, to evaluate follow-up or to confirm additional test results. At 10 of these 93 patients the treatment decision was changed (10.7\%). Compared with the GTB period, total number of endocrine surgeries, thyroid, parathyroid and adrenal gland surgeries were increased $(p=0.06, p=0.13, p=0.04$ and $p=0.09$, respectively) (Figure 4). The number of malignant thyroid cases and the requirement of prophylactic or therapeutic neck dissection were also increased $(\mathrm{p}=0.10$ and $\mathrm{p}=0.03$, respectively) (Figure 5 and Figure 6).

\section{DISCUSSION}

The value of MB meetings in terms of cancer diagnosis, treatment, and survival rates was first demonstrated in 1975 by Berman et al. (10). Subsequently, many oncologists and other specialists have advocated the establishment of such boards, and regular meetings of the boards, to improve the quality of disease management (11-13). Wright et al. (1) developed Canadian guidelines on the standards to be met by a multidisciplinary coun-

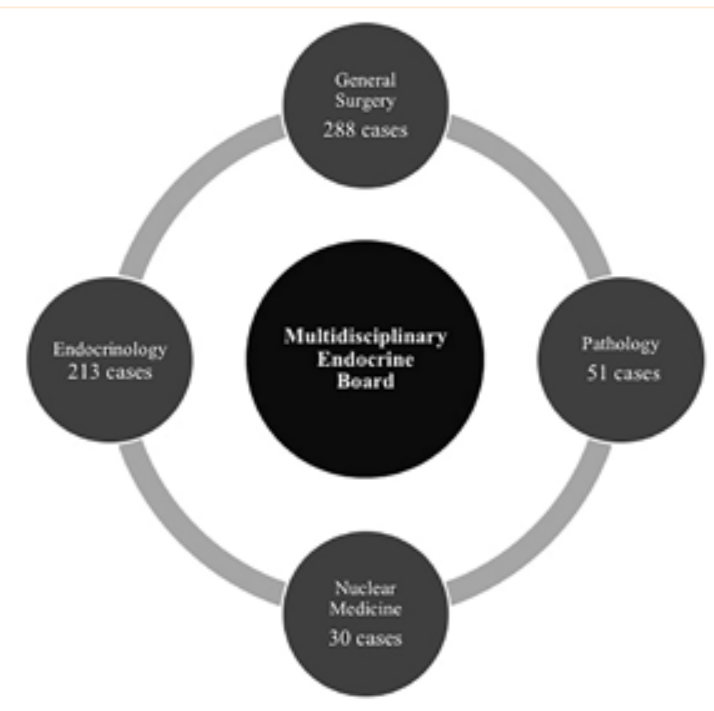

Figure 2. The distribution of the cases presented in the MEB by departments.

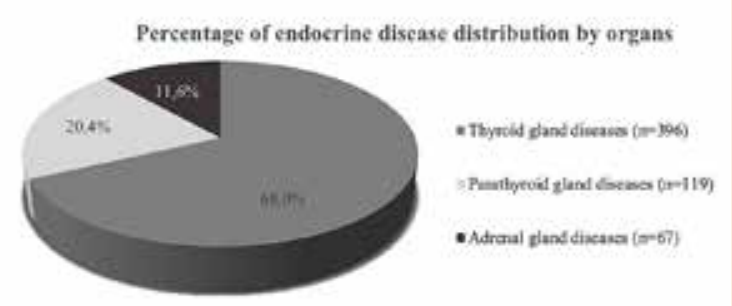

Figure 3. Distribution of diseases discussed in the MEB. 


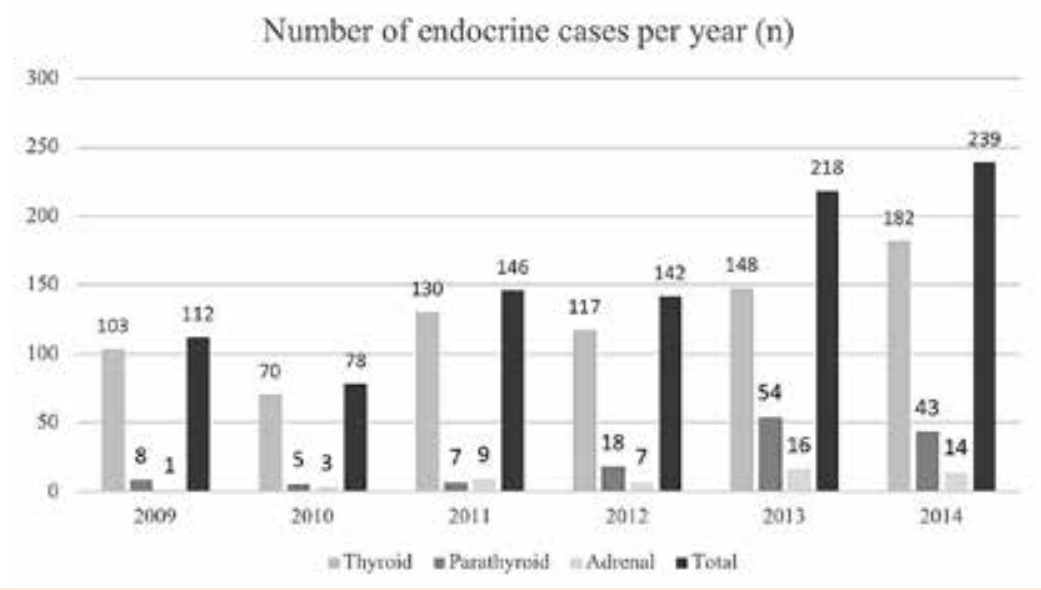

Figure 4. Distribution of patients who underwent thyroid, parathyroid and adrenal gland surgery in our department before and after the establishment of MEB in 2012. Total number of endocrine surgeries, thyroid, parathyroid and adrenal gland surgeries were increased $(p=0.06, p=0.13, p=0.04$ and $p=0.09$, respectively).

Malignant and all cases underwent surgery for thyroid gland diseases

(n)

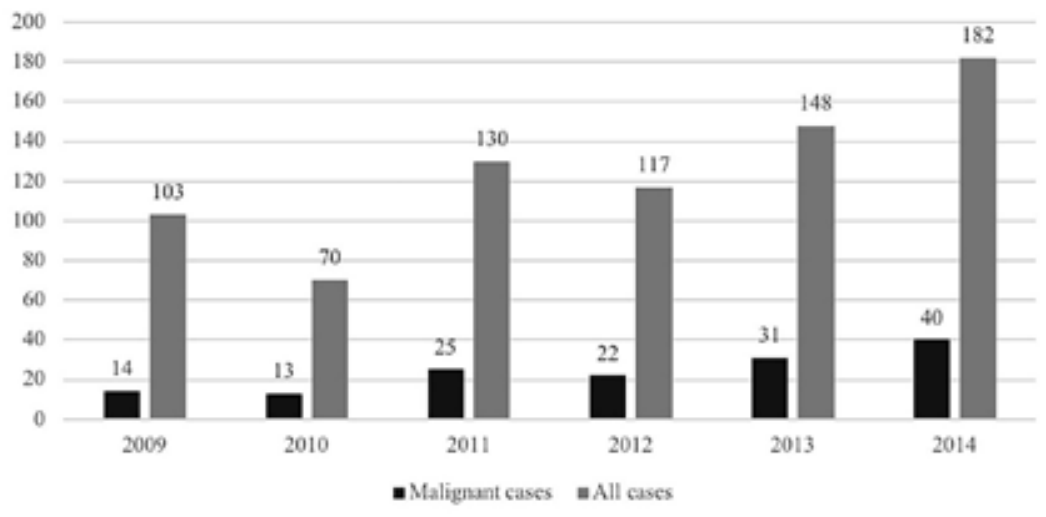

Figure 5. Distribution of thyroid cases including the number of malignant cases before and after the establishment of MEB in 2012. The rate of surgery for malignant thyroid cases increased from $14(13.5 \%)$ per year to $40(21.9 \%)$ per year $(p=0.1)$.

cil in 2006. The American Thyroid Association working group, reporting in 2012, emphasized the importance of communication between the medical and surgical disciplines involved in treatment of thyroid cancer. It was considered essential to evaluate both preoperative and operative findings. Indeed, the assessment of risk was as important as the histopathological data in determining the appropriate adjuvant treatment and follow-up (6). Most recent articles on MBs indicate that board discussions afford positive results in terms of diagnosis, treatment, management, and survival rates of cancer patients.
Stephan et al. (7) evaluated the effects of board discussions on the diagnosis, staging, and treatment plans for patients with head-and-neck tumors. In their study, examination of 9 weeks of board records showed that 120 patients were evaluated. Diagnoses were changed for $8 \%$ of patients, treatment plans were changed for $16 \%$, and both diagnoses and treatment plans were changed for approximately $27 \%$.

Hagen et al. (8) examined the effects of an MB on clinical decision-making for patients with gastrointestinal malignancies. Board discussions on 252 patients result- 


\section{Multidisciplinary board for endocrine diseases}

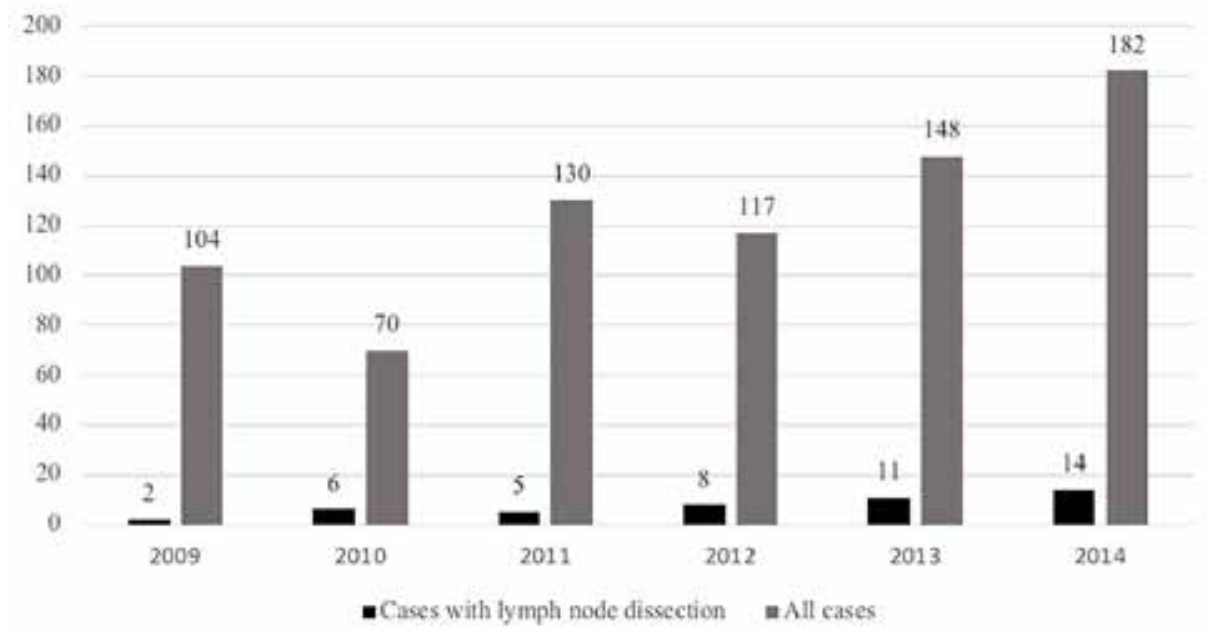

Figure 6. Distribution of prophylactic or therapeutic neck dissection in malignant cases before and after the establishment of MEB in 2012. The number of prophylactic or therapeutic lymph node dissection increased from $2(1.9 \%)$ per year to $14(7.6 \%)$ per year $(p=0.03)$.

ed in changes in treatment plans for $34.5 \%$ of patients. In our study, 92 patients were discussed in more than one MEB round. At 10 of these patients, the treatment decision was changed (10.7\%).

In the present study, the number of surgical interventions for all endocrine diseases, adrenal and parathyroid gland diseases were increased $(\mathrm{p}=0.06, \mathrm{p}=0.09$ and $\mathrm{p}=0.04$, respectively) compared with the GTB period (Figure 4). Furthermore, the number of patients with thyroid malignancies who underwent surgery and the number of neck dissections for malignant disease were increased ( $\mathrm{p}=0.10$ and $\mathrm{p}=0.03$, respectively) (Figure 5 and 6). We believe that, MEB employs a unified nomenclature, which facilitates appropriate disease management and increases the volume of more sophisticated endocrine cases in our surgery department.

Most of MBs principally discuss cancer. However, as endocrine diseases are complex, even the optimal management of benign pathologies is sometimes debatable. The literature contains data on boards reviewing benign diseases. Indeed, Traynor et al. (14) showed that patients with amyotrophic lateral sclerosis (ALS, which is benign but associated with high mortality) who were followed-up and treated in a multidisciplinary clinic lived an average of 7.5 months longer than those who were followed-up and treated in a general neurology clinic. The annual mortality rate fell by $30 \%$. According to this, 215 patients $(48.3 \%)$ with benign thyroid gland diseases were discussed at the MEB rounds in our study. In recent decades, MBs that consider oncological and breast surgeries have become the centers of disease management. In the complex field of endocrine surgery, we found that meetings independent of the general board, thus specialized meetings designed for endocrine disorders, were very valuable. In the present study, our surgery department presented $49.5 \%$ of all patients; other departments presented the remaining $50.5 \%$ of patients. This reflects reciprocal information exchange and good interdisciplinary communication; all branches conducted sophisticated planning prior to introducing patients for MB discussion. We believe that this generates good long-term results in terms of diagnosis, treatment, and follow-up.

\section{Limitations}

The retrospective design is the major limitation of this study. Another limitation was the different format of the boards: Adequate number of patients were achieved but no data was available for some of the parameters of MEB in the GTB period for the analysis. Thus, only available data for both periods were included in the analysis. Also, the period of the study consists just two years for each period and only short term effects of the boards are given such as patient profile, decision making and short term results relevant with the MEB results. Due to survival rate of the endocrine diseases is longer 


\section{Endokrin hastalıklar için multidisipliner kurullar}

than other malignancies, the study period may not be sufficient for the oncologic outcomes of these multidisciplinary boards. Therefore, a prospective study for the long term effects of the multidisciplinary endocrine boards and its surgical outcomes would be a topic for another clinical study.

Ethics Committee Approval: Ethics committee approval was received for this study from the ethics committee of Bakirkoy Dr. Sadi Konuk Training and Research Hospital (2015-137)

Informed Consent: Written informed consent was obtained from patients who participated in this study.

Peer-review: Externally peer-reviewed

Author Contributions: Concept - H.A.K., C.A.; Design - A.C.D., M.G.Ü.; Supervision - D.G., R.Y.; Resources - I.H., P.K. Materials - İ.H., H.A.K.; Data Collection and/or Processing - İ.H., H.A.K., M.G.Ü.; Analysis and/ or Interpretation - A.C.D., C.A., D.G., P.K., H.A.; Literature Search - İ.H., M.G.Ü, H.A.K.; Writing Manuscript H.A.K., A.C.D.; Critical Review - H.A., R.Y., P.K., C.A.; Other - İ.H., R.Y., D.G.

Acknowledgement: We would like to thank Drs. Meral Mert and Ozlem Selçukbiricik, specialists in the Department of Endocrinology; Dr. Murat Sipahi and Dr. Aysel Koyuncu, specialists in the Department of Nuclear Medicine; and Dr. Hürriyet Turgut, specialist in the Department of Pathology for their valuable contributions to this study.

Conflict of Interest: No conflict of interest was declared by the authors.

Financial Disclosure: The authors declared that this study has received no financial support.

Etik Komite Onayı: Bu çalışma için etik kurul onayı Bakırköy Dr. Sadi Konuk Eğitim ve Araştırma Hastanesi'nden alınmıştır. (2015-137)

Hasta Onamı: Yazılı hasta onamı bu çalışmaya katılan hastalardan alınmıştır.

Hakem Değerlendirmesi: Dış Bağımsız

Yazar Katkıları: Fikir - H.A.K., C.A.; Tasarım- A.C.D., M.G.Ü.; Denetleme - D.G., R.Y.; Kaynaklar - İ.H., P.K. Malzemeler - İ.H., H.A.K.; Veri Toplanması ve/veya İşlemesi - İ.H., H.A.K., M.G.Ü.; Analiz ve/veya Yorum -
A.C.D., C.A., D.G., P.K., H.A.; Literatür Taramas1 - İ.H., M.G.Ü, H.A.K.; Yazıyı Yazan - H.A.K., A.C.D.; Eleștirel İnceleme-H.A., R.Y., P.K., C.A.; Diğer-İ.H., R.Y., D.G.

Teşekkür: Bu çalışmadaki değerli katkılarından dolay1 Endokrinoloji Bölümünden Uzm. Dr. Meral Mert ve Uzm. Dr. Özlem Selçuk Biricik'e, Nükleer Tıp Bölümünden Uzm. Dr. Murat Sipahi ve Uzm. Dr. Aysel Koyuncu'ya, Patoloji Bölümünden Uzm. Dr. Hürriyet Turgut'a teşekkür ederiz.

Çıkar Çatışması: Yazarlar çıkar çatışması bildirmemişlerdir.

Finansal Destek: Yazarlar bu çalı̧̧ma için finansal destek almadıklarını beyan etmişlerdir.

\section{REFERENCES}

1. Wright FC, De Vito C, Langer B, Hunter. Multidisciplinary cancer conferences: a systematic review and development of practice standards. Eur J Cancer 2007;43(6):1002-10. [CrossRef]

2. Nguyen NP, Vos P, Lee H, Borok TL, Karlsson U, Martinez T et al. Impact of tumor board recommendations on treatment outcome for locally advanced head and neck cancer. Oncology 2008;75(3-4):186-91. [CrossRef]

3. Santoso JT, Schwertner B, Coleman RL, Hannigan EV. Tumor board in gynecologic oncology. Int J Gynecol Cancer 2004;14(2):206-9. [CrossRef]

4. Keating NL, Landrum MB, Lamont EB, Bozeman SR, Shulman LN, McNeil BJ. Tumor boards and the quality of cancer care. J Natl Cancer Inst 2013;105(2):11321. [CrossRef]

5. Güler SA, Cantürk NZ. Multidisciplinary breast cancer teams and proposed standards. Ulus Cerrahi Derg 2014;31(1):39-41.

6. Carty SE, Doherty GM, Inabnet WB 3rd, Pasieka JL, Randolph GW, Shaha AR et al; American Thyroid Association statement on the essential elements of interdisciplinary communication of perioperative information for patients undergoing thyroid cancer surgery. Thyroid 2012;22(4):395-9. [CrossRef]

7. Wheless SA, McKinney KA, Zanation AM. A prospective study of the clinical impact of a multidisciplinary head and neck tumor board. Otolaryngol Head Neck Surg 2010;143(5):650-4. [CrossRef]

8. van Hagen P, Spaander MC, van der Gaast A, van Rij CM, Tilanus HW, van Lanschot JJ, et al. Rotterdam Oesophageal Tumour Study Group. Impact of a multidisciplinary tumour board meeting for upper-GI malignancies on clinical decision making: a prospective cohort study. Int J Clin Oncol 2013;18(2):214-9. [CrossRef] 
9. Dural AC, Akarsu C, Unsal MG, Büyükaşık S, Çelik MF, Soyluk Selçukbiricik Ö, et al. Multidisciplinary management of surgery for thyroid diseases: Analysis of five years with the experience of Bakirkoy Dr. Sadi Konuk Education and Research Hospital. Endokrinolojide Diyalog 2015;12(1):1-8. [CrossRef]

10. Berman HL. The tumor board: is it worth saving? Mil Med 1975;140(8):529-31.

11. Fennell ML, Das IP, Clauser S, Petrelli N, Salner A. The organization of multidisciplinary care teams: modeling internal and external influences on cancer care quality. J Natl Cancer Inst Monogr 2010;40:7280 .
12. Fleming ID. Multidisciplinary treatment planning. Tumor boards. Cancer 1989;64(1 Suppl):279-81. [CrossRef]

13. Snelgrove RC, Subendran J, Jhaveri K, Thipphavong $\mathrm{S}$, Cummings B, Brierley J, et al. Effect of multidisciplinary cancer conference on treatment plan for patients with primary rectal cancer. Dis Colon Rectum 2015;58(7):653-8. [CrossRef]

14. Traynor BJ, Alexander M, Corr B, Frost E, Hardiman O. Effect of a multidisciplinary amyotrophic lateral sclerosis (ALS) clinic on ALS survival: a population based study, 1996-2000. J Neurol Neurosurg Psychiatry 2003;74(9):1258-61. [CrossRef] 